\title{
Communication Processes as a Tool of Cooperation and Regional Development
}

\author{
Agnieszka Rzepka \\ Lublin University of Technology, Lublin, Poland \\ Andrzej Jan Olak \\ The Bronisław Markiewicz State Higher School of Technology and Economics in Jaroslaw, Jaroslaw, Poland
}

\begin{abstract}
The aim of the following article is to illustrate the importance of selected aspects of communication processes that clearly imply regional development. To emphasize the crucial factors of economic development of regions and states, one has to approach this process in an interdisciplinary manner. Methods and techniques of communication significantly gain in importance. In the long term, the development of a state will be determined by a continuous development of regions, assisted by the processes of communication. This is a real challenge for those who seek new methods of effective management. In this article there has presented an empirical verification of chosen aspects of communication, understood as a synergy of creativity and innovation based on Centre for Professional Education in Stalowa Wola in Podkarpackie voivodeship. A research procedure and tools as well as results or carried out analysis were presented. The basic research tool was a questionaire. In this article the authors hypothesized the following: Mixed forms of communication are an important factor contributing to regional development. The processes of communication are a crucial tool of cooperation and create the environment for local and regional development.
\end{abstract}

Keywords: processes of the communication, regional development, creativity, innovation

\section{Introduction}

Continuous and dynamic development of regions and states leads to a permanent quest for novel systemic solutions, the aim of which is to increase the efficiency of human action. As a result of growing competition between various domains of human activity, natural elements of human behavior gain in importance, as these will be the factors that will indicate the most effective methods of fulfilling all the needs-both the basic and the higher-level ones. Business entities and organizations that influence the development of regions have to rise up to the challenges peculiar to the current phase of civilization and cultural development. Effective identification of these challenges is the determinative factor in the development processes in local and regional communities.

Agnieszka Rzepka, Ph.D., assistant proffessor, Department of Economics and Management of Economy, Lublin University of Technology, Lublin, Poland.

Andrzej Jan Olak, Ph.D., assistant proffessor, Departament of Management, The Bronisław Markiewicz State Higher School of Technology and Economics in Jaroslaw, Jaroslaw, Poland.

Correspondence concerning this article should be addressed to Agnieszka Rzepka, Faculty of Management, Lublin University of Technology, Nadbystrzucka Street 38, 20-618 Lublin, Poland. 
Continuous quest for new solutions that will guarantee development—or even survival—has to be based on knowledge, intuition, and human experience. All the actions that are inherently pragmatic and correspond to good communication will form an effective imperative for the improvement of methods and ways of regional development.

\section{Communication as a Tool of Motivation and Development}

The Polish terms such as "komunikacja", "komunikowanie", "komunikowanie się" are the translations of the English terms "communication" and "communicate" (Potocki, Winkler, \& Żbikowska, 2003, p. 32). The concept of "communication" appears in many academic disciplines, including psychology, sociology, cybernetics, biology, and humanities. Communication is set of complementary processes understood as continuous and unremitting exchange of information between the participants of these processes.

Human behavior is a crucial factor in the both professional and private life of each individual. For the point of view of an organization and its development, this factor is responsible for our satisfaction (or lack thereof) with all the professional and social relations that we are engaged in. Human behavior may become (...) a solid basis of public support, (...) and the source of synergy, because (...) "mutually-supportive people who experience good cooperation may accomplish much more than those who do not support each other and cannot cooperate" (Griffin, 2006, p. 591). In modern organization where process management is the dominant ensemble of practices, communication is perceived as "affiliate" philosophy — as a modern management style.

Communication should be treated as a process that enables us to interpret information through some contractual messages. Thus, the following question arises: is ideal communication possible in reality? In fact, it is impossible to trigger exactly the same "image" in the recipient as it was in the intentions of the sender. In the process of communication, i.e., the flow of information from one person to another, what counts is the effectiveness. People think, talk, and act-"Everyone who develops in these three domains will discover that everything goes well in their hands" (Buber, 1959, p. 155). As a consequence, we struggle for a redundancy rather than entropy, that is, the state in which the message is proximate to the intentional one. There are internally complex processes of information evaluation conditioned by numerous (psychological) personality, social, economic, and cultural variables, all of which shape the mechanisms of market behavior (Blythe, 2002, pp. 24-25). The processes of communication may and should serve as a tool that motivates to take up various action that will lead to a broadly perceived development. What is useful here is the concept of relevance which enables to separate relevant elements of methods of verbal communication. It "forces" the recipient to be more creative and inquisitive about the intentions of the sender, but always on the assumption that we exclude advanced social engineering and manipulation from this category. In some situations during the communication process we experience a typical communicative event which is counseling. It takes place when the level of trust in the interlocutor is low or we do not trust them at all. According to Kagan (1975), "as a matter of fact we indirectly tell someone 'You make song and dance of a problem the solution to which is for me instantly obvious-you are so stupid" (Kagan, 1975, p. 29). Such events also take place at the level of organization and lead to numerous consequences. An ubiquitous phenomenon in interpersonal relations is manipulation, where it is not always true that to be praised means to be accepted. Praise often becomes a method to exploit other people. It often enables to outfox and outmanoeuvre with sweet nothings (Augsburger, 1973, p. 110).

In order to avoid or limit unfavorable phenomena that influence the development of organizations stimulating the regional development, one has to focus on the quality and scope of information which is 
determined by knowledge of the above mentioned human behavior.

Information is, therefore, a necessary tool in the hands of organizations that function in an effective and modern way. In the decision-making processes it is information that is required to set and carry out tasks that are helpful in setting the goals of the organization, as it enables to decrease uncertainty "about the current or future state of affairs, which it refers to" (Czekaj, 2000, p. 127).

In the light of the variety of concepts related to the development of both organizations and regions, one has to refer to the concept of emotional intelligence put forward by Goleman (1997). At this stage we may propose the following thesis: why is emotional intelligence crucial to the regional development? This is because it indicates psychological factors of local community members and enables to expose elements such as attachment to a particular environment or culture. What confirms this thesis is the activity of local communities that create the environment and "climate" for local and regional development. Recently, following Gardner, more and more psychologists come to similar conclusions that the old concepts of IQ revolve around a narrow domain of language and mathematical skills, and the results of IQ tests might serve as a forecast of successes in education or academic career, but only to a lesser extent do they determine the success in other domains of life (Goleman, 1997, p. 80). The crucial aspect of these considerations is to build and consolidate emotional competence through empathy. One of the influential definitions of empathy includes the following phrase: "it is an experiencing of the consciousness 'behind' another's outward communication, but with continuous awareness that this consciousness is originating and proceeding in the other" (Barrett-Lennard, 1962, p. 144). Empathic paraphrasing is the most important skill here. In the words of Bolton (1979), "a paraphrase is a concise verbal reaction to the interlocutor, which expresses the essence of his/her content articulated in the hearer's own words" (Bolton, 1979, p. 51). Shaping emotional competence has a major impact on the process of interpersonal communication which works like communicating vessels that involve the following three elements: psychological competence, social competence, and praxeological competence. Appropriate work environment can be defined by shaping relations, exchange of knowledge, and communicativeness of local and regional community members. Major changes that currently take place and fierce competition pose more and more challenges.

Apart from creativity and innovation, it is interpersonal communication that is important. This is a common element of life and in the future it will become the tool of motivation and development of regions and the state.

\section{Regional Development as a Complex Process}

Continuous and systematic changes in the surrounding pose new challenges connected with systemic solutions to all the organizations. New ideas and solutions are introduced in all domains of life. To meet the continuously growing requirements, all the organizations - irrespective of their size and structure-introduce various innovations that modify or reshape their structure.

By this process organizations that stimulate local and regional development try to stay on the market and/or consolidate their strategic position. Most of the changes are endogenous and exogenous and influence both the macro- and micro-surrounding of the organizations and the region. In the current economy endogenous, factors of regional and local development over balance the exogenous ones. The latter one cannot substitute the former; they can only serve as a support. If there is no home capability or if it is very weak, even a significant intervention from outside will not alter it (Brdulak, 2001, p. 95). 
Regional development treated as a process is a very complex phenomenon determined by a number of psychological, cultural, and economic factors, and cultural factors are of particular importance here. Social groups create some episodes and activities that constitute affective relations. For an individual, these are "internal cognitive representations of common, repeatable and routine interactions within a defined cultural environment" (Forgas, 1981, pp. 165-180).

Needs of people are satisfied in an ongoing and infinite way. Thus, the following question arises: how, through natural means, to increase the awareness of society that performs this difficult process? With appropriate bilateral communication which is comprehensible for the majority of local or regional community members and shapes the awareness of local brands and their potential, we increase the chances that the society will accept regional development. It is similar to the concept of branding - the process of generating positive associations in the minds of potential and real clients. The justification of such an approach can be found in the rule of persuasion, which says that we like what we know (Majewski, 2007, p. 15). The understanding of it enables to activate employees and stimulate bigger creativity of both inhabitants and the entire surrounding of a particular region. Management that embraces branding requires managers to pay more attention, because it involves more personality traits of this process participant. Managing in such a complex structure will be based on professional management of sign transfers, because only then can the information absorption process be "usefully transformed". Success depends on the degree of accuracy in identification of opportunities and threats in the surrounding. The characteristic elements of all analyses is anticipation of development constraints and the ability to formulate strategies not on the basis of forecasts, but "on the basis of deduction based on changes that have already taken place in the environment or were identified in the past as changes to take place in the future" (Gierszewska \& Romanowska, 1994, p. 48). These considerations serve as a suggestion that our ways of thinking, managing, and leadership should change. New levers for leadership entail more collegial, voluntary, and bidirectional relations that are to ensure the formation of community to which clients will want to belong (Gobillot, 2008, p. 96). The need to create another environment that has its moral and social dimension - and not only the economic one-means that the factors that are responsible for the success of leadership are completely different.

The greater the public awareness is, the bigger local and regional development takes place. "Human activity is connected with the effectiveness of local institutions, which translates into economic developments" (Rzepka, 2016, p. 41). The existence of social institutions increases both the ability to resolve conflicts and the mutual trust of all the participants of economic life. It becomes crucial to big cities, towns, and villages. Therefore, various activities targeted at increasing the importance of society will in the long run influence local and regional economy. Within a community, the importance of local communication, local information flow, and the resulting meaning of media that take part in these processes, refers to the political-democratising, economic and cultural dimensions of functioning. Permanent fusion of these elements may guarantee regional and state development.

\section{Methodology_Processes of Communication as Tools of Cooperation and Regional Development in Research}

The following chapter presents the empirical verification of selected aspects of communication perceived as tool of cooperation in regional development. It includes the presentation of research procedure, research tools, and the results of the analysis conducted. The aim of the study is to analyse the importance of communication and its various forms in management and development of local authorities. 
The analysis conducted in the following chapter will serve as a basis to verify hypotheses presented in the this article.

In the research the following hypotheses were proposed:

(1) Mixed forms of communication are an important factor contributing to regional development;

(2) The processes of communication are a crucial tool of cooperation and create the environment for local and regional development.

The basic tool was the survey questionnaire. The research was conducted in the first quarter of 2012.

The survey included 300 randomly selected inhabitants of Rudnik, Nisko, and Krosno communes in the Podkarpackie voivodeship (Poland). The gender structure of the respondents was the following: 142 women (which gives $47.3 \%$ of respondents) and 158 men (52.7\% of respondents). When it comes the education, $40 \%$ of respondents had higher education, $37.7 \%$ of respondents had secondary education, $14.3 \%$ of respondents had secondary general and vocational education, and $8 \%$ had vocational education. Figure 1 below illustrates the structure of respondents' education.

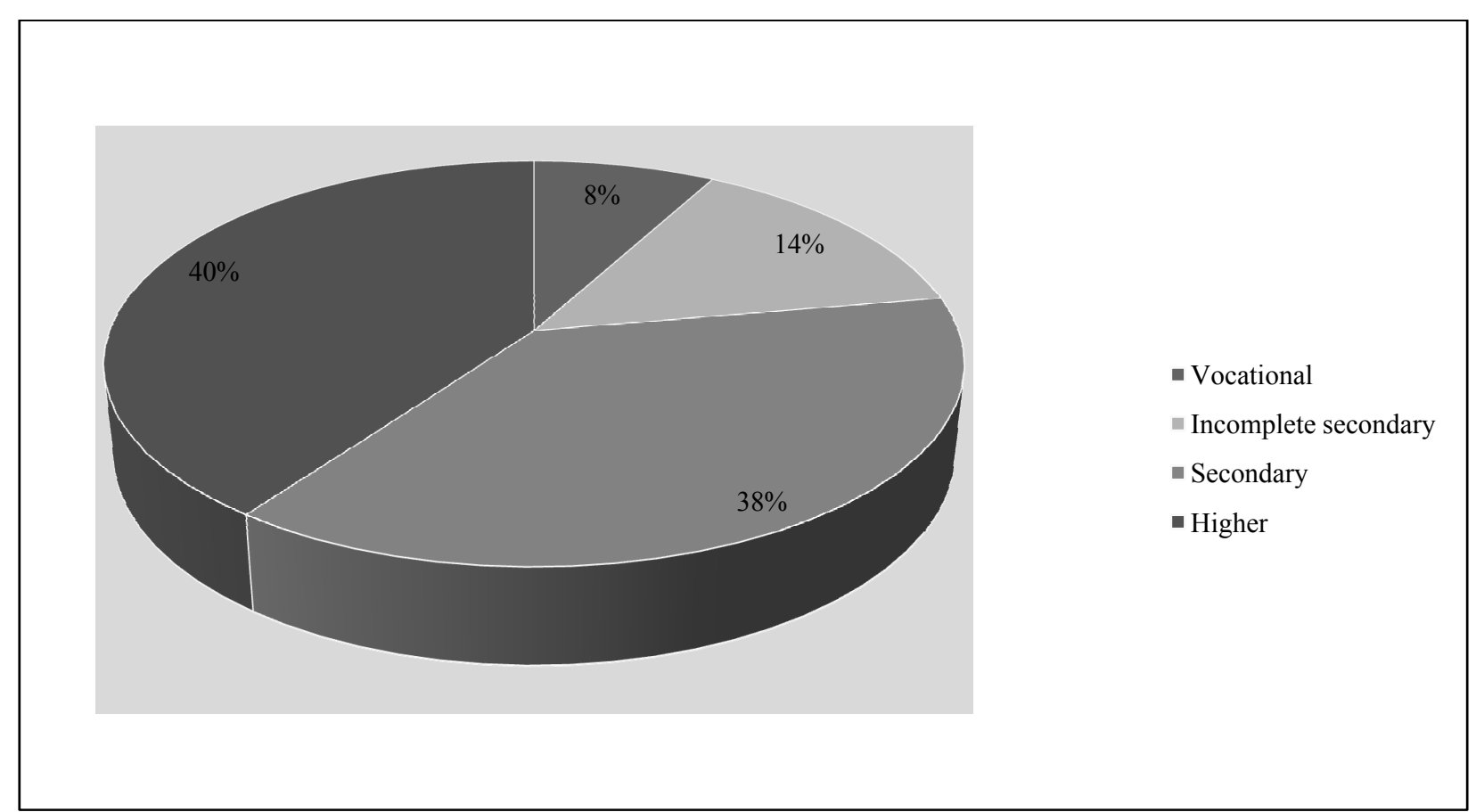

Figure 1. The structure of respondents' education. Source: Own elaboration based on the survey.

The research has shown that $70 \%$ of respondents are interested in the current affairs connected with the functioning of commune self-government (activities and initiatives taken up by the voyt and the self-government), while the remaining $30 \%$ of respondents do not have such an interest. Figure 2 below illustrates the answers to this question.

The respondents have also stipulated their attitude to whether they have a sufficient influence on the activities of the commune authorities, so - also - whether the messages they send are a tool of effective cooperation being an essential element of development. The results of the research have shown that $7.7 \%$ of respondents think that they definitely have such an influence, $35.7 \%$ of respondents think that they rather have it, $14 \%$ of respondents answered that they do not have such an influence, and $11.3 \%$ of respondents answered 
"neither yes nor no". Table 1 below illustrates the relation between respondents' answers to this question and their education.

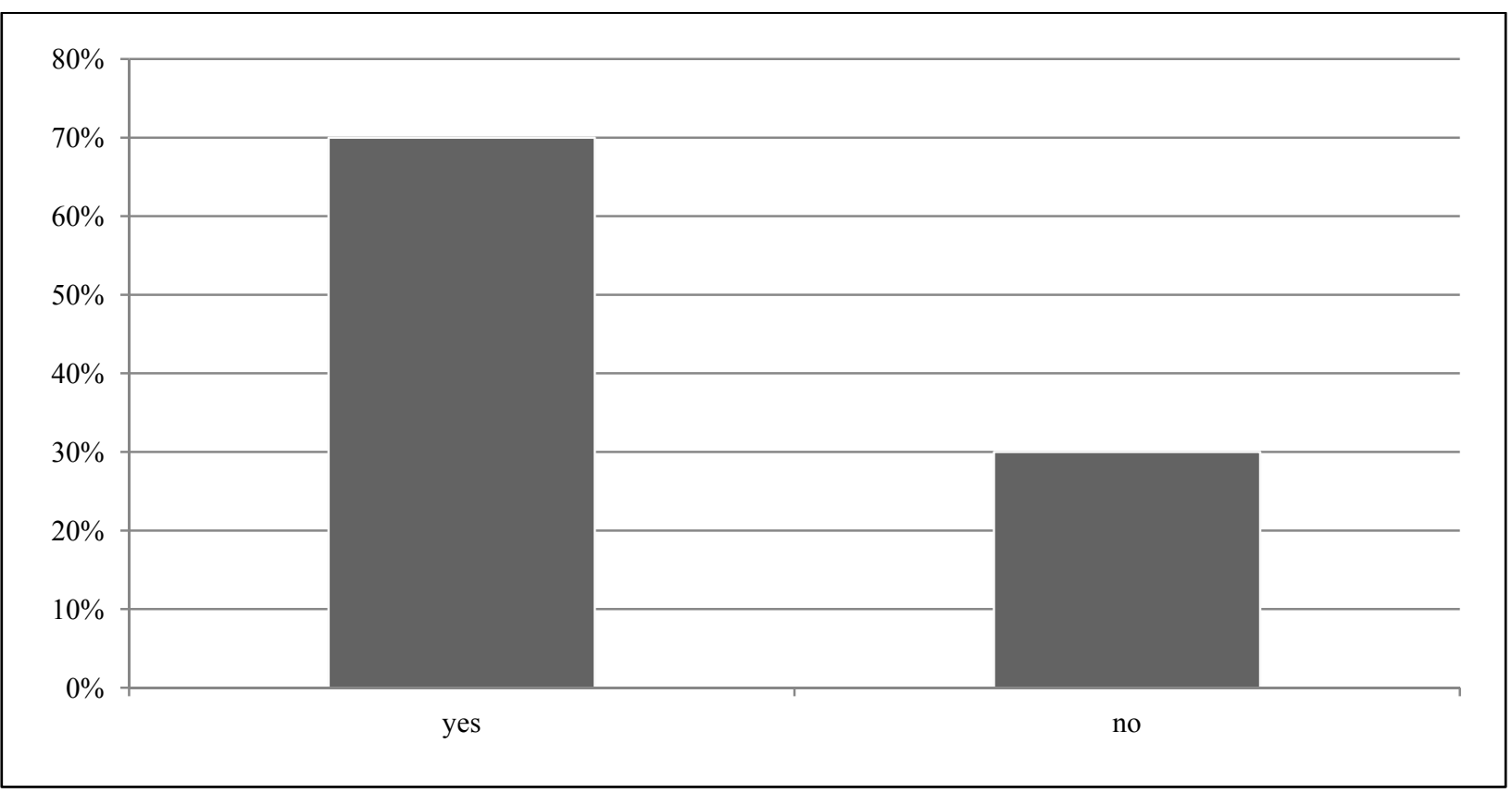

Figure 2. Response to the question "Are you interested in the current affairs connected with the functioning of commune?" Source: Own elaboration based on the survey.

Table 1

Respondents' Opinions About Their Influence on the Decisions of Commune Authorities

\begin{tabular}{|c|c|c|c|c|c|c|c|c|c|c|}
\hline \multirow{3}{*}{$\begin{array}{l}\text { Question 2. Do you think that you } \\
\text { have a sufficient influence on the } \\
\text { activities of the commune? }\end{array}$} & \multicolumn{8}{|c|}{ Education } & \multicolumn{2}{|c|}{ Total } \\
\hline & \multicolumn{2}{|c|}{ Vocational } & \multicolumn{2}{|c|}{$\begin{array}{l}\text { Incomplete } \\
\text { secondary }\end{array}$} & \multicolumn{2}{|c|}{ Secondary } & \multicolumn{2}{|c|}{ Higher } & \multirow[t]{2}{*}{$\mathrm{N}$} & \multirow[t]{2}{*}{$\%$} \\
\hline & $\mathrm{N}$ & $\%$ & $\mathrm{~N}$ & $\%$ & $\mathrm{~N}$ & $\%$ & $\mathrm{~N}$ & $\%$ & & \\
\hline Definitely yes & 1 & 2.3 & 1 & 4.2 & 12 & 10.6 & 9 & 7.5 & 23 & 7.7 \\
\hline Rather yes & 11 & 25.6 & 6 & 25.0 & 47 & 41.6 & 42 & 35.0 & 106 & 35.3 \\
\hline Rather no & 14 & 32.6 & 7 & 29.2 & 32 & 28.3 & 42 & 35.0 & 95 & 31.7 \\
\hline Definitely no & 7 & 16.3 & 6 & 25.0 & 13 & 11.5 & 16 & 13.3 & 42 & 14.0 \\
\hline Neither yes nor no & 10 & 23.2 & 4 & 16.6 & 9 & 8.0 & 11 & 9.2 & 34 & 11.3 \\
\hline Total & 43 & 100.0 & 24 & 100.0 & 113 & 100.0 & 120 & 100.0 & 300 & 100.0 \\
\hline
\end{tabular}

Source: Own elaboration based on the survey.

It has to be noted that in the group of respondents with secondary education there were two highest scores for "definitely yes" and "rather yes". Nevertheless, the highest percentage of respondents who answered "rather no" were those with higher education. The answer "definitely not" was the most common the group of respondents with incomplete secondary education. The answer "neither yes nor no" was most frequently chosen by respondents with vocational education.

Below, there are respondents' opinions about the methods that commune authorities use to communicate with the inhabitants. The list goes from the most popular to least popular:

- Information boards and cases $-46.2 \%$ of answers.

- Commune office bulletin-18.4\% of answers. 
- Direct contact of commune authorities and inhabitants- $17.7 \%$ of answers.

- Cooperation with media to inform public about the activity of commune authorities $-8.6 \%$ of answers.

- Catalogue of services offered by the commune- $6.1 \%$ of answers.

- Civic mail boxes-3\% of answers.

Another issue analysed the respondents' opinion about whether the commune promotes itself outside. About $44.7 \%$ of respondents gave a positive answer and $14 \%$ of respondents gave a negative answer. The remaining $41.3 \%$ of respondents had a neutral attitude and chose the answer "I don't know". Figure 3 below presents the structure of answers to this question.

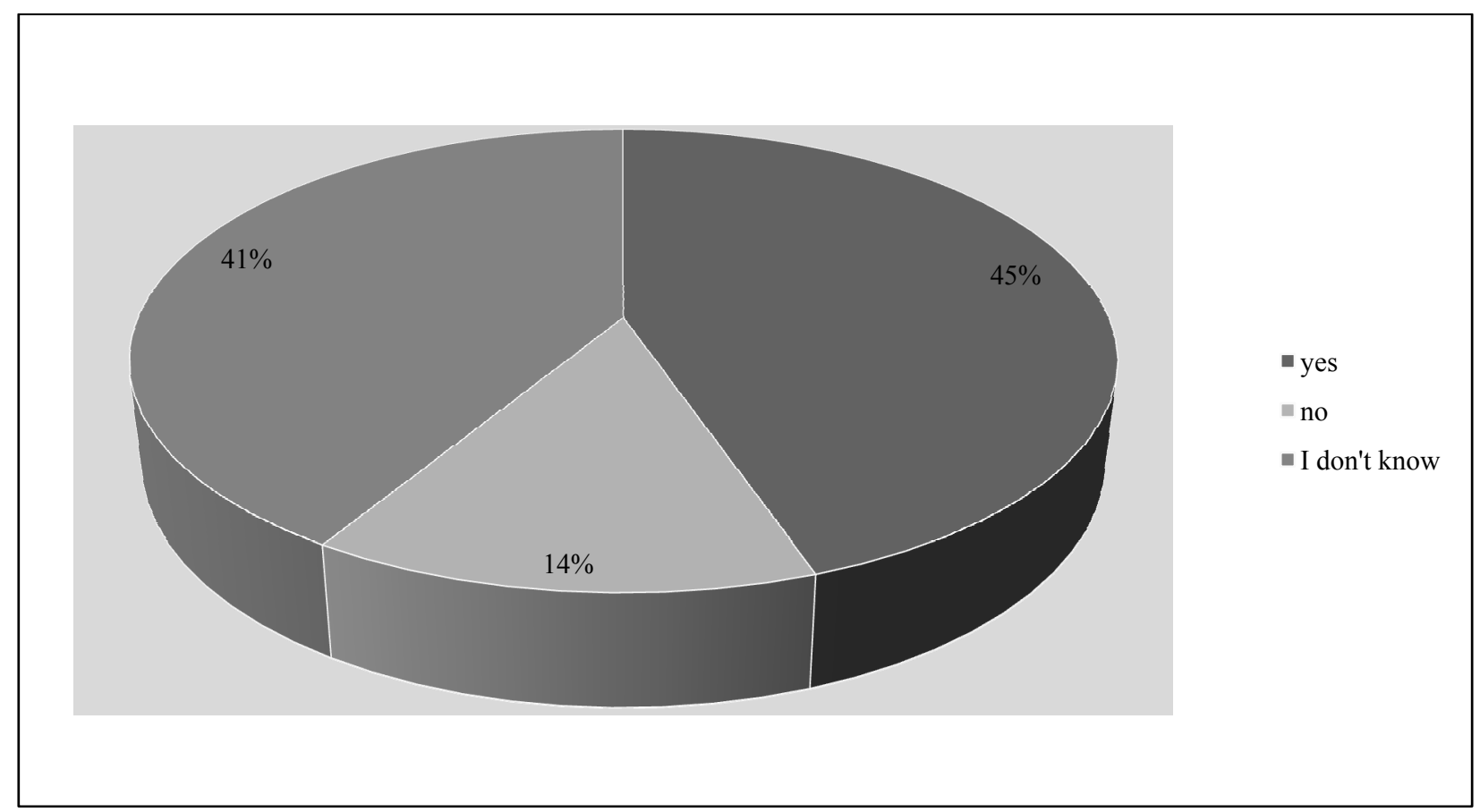

Figure 3. The structure of answers to the question "Does the commune promote itself outside?". Source: Own elaboration based on the survey.

Question 5 was related to the respondents' attitude to promotion forms that commune authorities may use. The following list illustrates the percentage of answers for each of the points:

- Participation in tourism fairs: $26 \%$ of respondents think that this form of promotion is used, $20.7 \%$ think that it is not; the rest do not know if the commune uses the form of promotion;

- Billboards and posters in other districts and voivodeships-21\% of respondents think that this form of promotion is used, $20.7 \%$ think that it is not; the rest do not know if the commune uses the form of promotion;

- Paid advertising in the press: $38.3 \%$ of respondents think that this form of promotion is used, $20.7 \%$ think that it is not; the rest do not know if the commune uses the form of promotion;

- Paid advertising on television: $24 \%$ of respondents think that this form of promotion is used, $31 \%$ think that it is not; the rest do not know if the commune uses the form of promotion;

- Paid advertising in the radio: $26 \%$ of respondents think that this form of promotion is used, $29.7 \%$ think that it is not; the rest do not know if the commune uses the form of promotion;

- Paid advertising on the Internet: $50.3 \%$ of respondents think that this form of promotion is used, $12.7 \%$ think that it is not; the rest do not know if the commune uses the form of promotion. 
- Leaflets/folders sent to travel agencies and tourism organizations: $25.3 \%$ of respondents think that this form of promotion is used, $18.7 \%$ think that it is not; the rest do not know if the commune uses the form of promotion.

Another important issue that defines the commune's ability to attract external investors, is a direct factor supporting economic development and development in general. Almost half of the respondents $(49 \%)$ are satisfied with the activities of the commune that are related to this topic, $13.7 \%$ of respondents have a contrary opinion, while the rest answer "I don't know".

By means of a Kruskal-Wallis ${ }^{1}$ non-parametric test, it was proved that the opinion about the commune's ability to attract external investors depends on the interest in the current affairs connected with the functioning of the commune self-government. Value $p$ gave 0 , so it was less that the adopted significance level $\alpha=0.1^{2}$.

Another topic referred to in the research was the respondents' awareness of the existence of a strategic document such as Strategy of Commune Development or Strategy of Commune Promotion. About 38.3\% of respondents think that such a document exists. Only $4.3 \%$ of respondents have a different opinion. The rest choose the answer "I don't know". Figure 4 below presents the structure of these answers:

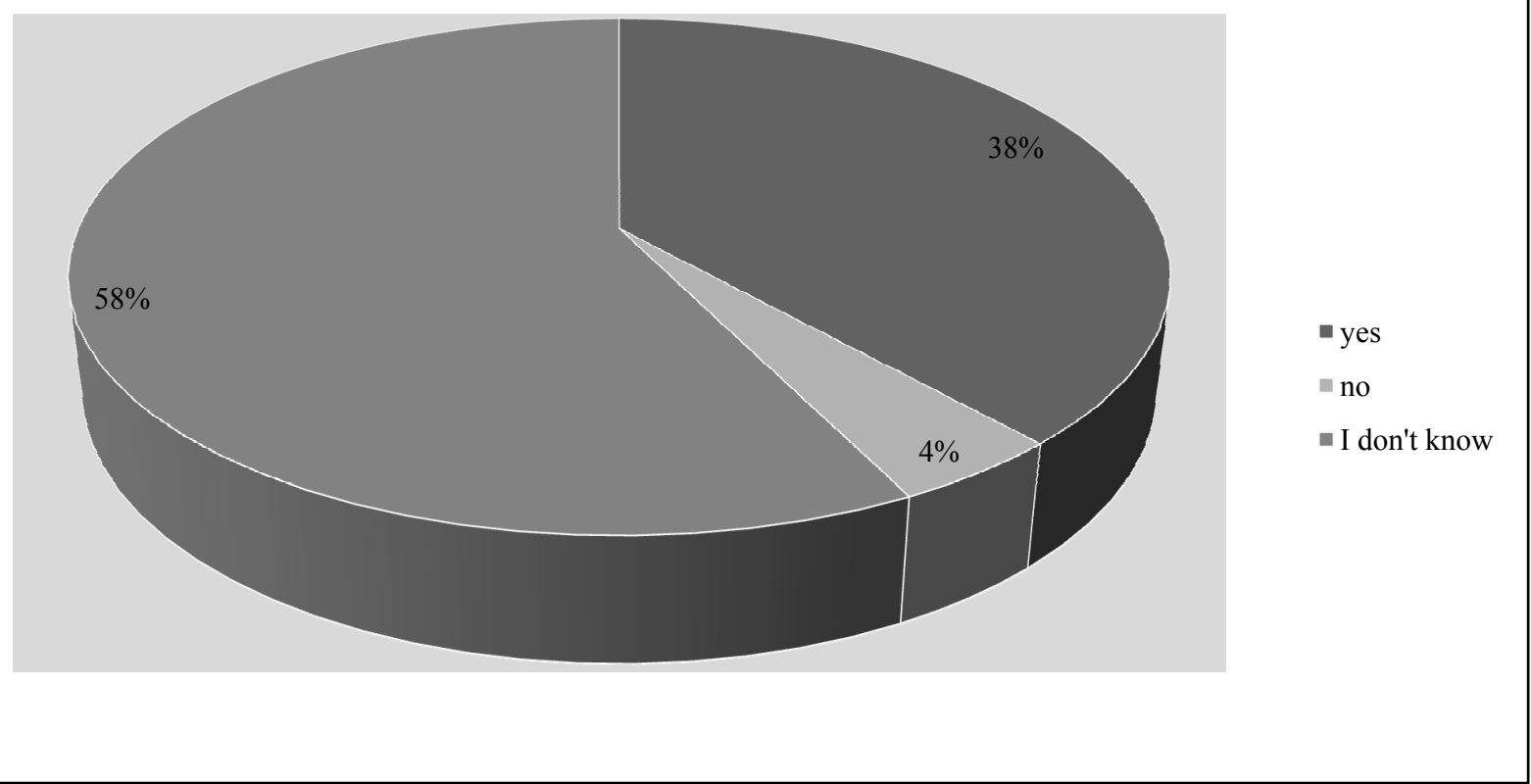

Figure 4. Structure of answers to the question "Does the commune have a strategic document (Strategy of Commune Development or Strategy of Commune Promotion)?” Source: Own elaboration based on the survey.

\footnotetext{
${ }^{1}$ The calculations were done using the SPSS Statistics 20.0 software. The hypotheses of Kruskal-Wallis test: $\mathrm{H}_{0}$ : the distribution functions of the analysed distribution are equal - the interest in the commune's activity does not diversify the answers to questions from the variables under analysis, $\mathrm{H}_{1}$ : the distribution functions of the analysed distribution are different- the interest in the commune's activity diversifies the answers to questions from the variables under analysis. We compare the set value $P$ (in the tables it is referred to as "asymptotic significance" with the significance level of $\alpha$ : if $\mathrm{p} \leq \alpha$, then we reject $\mathrm{H}_{0}$ and simultaneously adopt $\mathrm{H}_{1}$ - there is a relation between the interest in the activities of the commune and the variable under analysis, if $p>\alpha$ then there is no point to reject $\mathrm{H}_{0}$ - the interest in the activities of the commune does not determine the variable under analysis.

${ }^{2}$ Due to the fact that data refer to a survey of respondents' opinions and not "hard" data, the author adopted the significance level of 0.1 instead of 0.05 .
} 
The respondents also expressed their attitude to whether the promotional activities taken up by the commune are sufficient. About $6.4 \%$ of them think that the communes do all they should, $25.3 \%$ think that this activity is sufficient, but its scope should be expanded, $42 \%$ think that there are such activities, but it is definitely not enough, $7.3 \%$ think that there are no such activities at all. The remaining $19 \%$ give the answer "I don't know". Table 2 below illustrates the structure of these answers.

The biggest group that had the opinion that there are some activities, but there is not enough of them was the group of women (40.9\%). Also the group of man (43\%) was the biggest one to give the same answer. The least popular answer among women was "there are no such activities" (5.6\%), and among men "complete, the authorities do all that they should" (6.3\%).

Additionally, by means of Kruskal-Wallis ${ }^{3}$ non-parametric test it was proved that the answer to the question "Does the commune have a strategic document such as Strategy of Commune Development or Strategy of Commune Promotion?" determines the opinions about the scope of activities taken up by the commune. Value $p$ gave 0 , so it was less that the adopted significance level $\alpha=0.1^{4}$.

Table 2

Opinions About Promotional Taken up by the Commune

\begin{tabular}{|c|c|c|c|c|c|c|}
\hline \multirow{3}{*}{ Question 9. Do you think that promotional activities are: } & \multicolumn{4}{|c|}{ Gender } & \multirow{3}{*}{\multicolumn{2}{|c|}{$\begin{array}{c}\text { Total } \\
\%\end{array}$}} \\
\hline & \multicolumn{2}{|c|}{ Woman } & \multicolumn{2}{|c|}{ Man } & & \\
\hline & $\mathrm{N}$ & $\%$ & $\mathrm{~N}$ & $\%$ & & \\
\hline Complete, the authorities do all that they should & 9 & 6.3 & 10 & 6.3 & 19 & 6.4 \\
\hline Sufficient, but there could be more of them & 42 & 29.6 & 34 & 21.5 & 76 & 25.3 \\
\hline There are some activities, but not enough of them & 58 & 40.9 & 68 & 43.0 & 126 & 42.0 \\
\hline There are no such activities & 8 & 5.6 & 14 & 8.9 & 22 & 7.3 \\
\hline Neither yes nor no & 25 & 17.6 & 32 & 20.3 & 57 & 19.0 \\
\hline Total & 142 & 100.0 & 158 & 100.0 & 300 & 100.0 \\
\hline
\end{tabular}

Source: Own elaboration based on the survey.

\section{Conclusions}

Problems that lie ahead of regions perceived as an integral system, and related to the direction, scale, and rate of development processes require a long temporal horizon, professional management, creativity of the authorities on all levels of self-government, systematicity, and schedule for development decisions to be made.

The crucial element of it is to resort to thorough knowledge and skillful application of novel management techniques. It means that there is a need to simplify and integrate horizontal and bidirectional information flow systems. The solution to it is to gradually substitute traditional administrative methods (loose and inconsistent organizational, economic, and technical solutions) with modern ones that are based on strategic and process

\footnotetext{
${ }^{3}$ The calculations were done using the SPSS Statistics 20.0 software. The hypotheses of Kruskal-Wallis test: $\mathrm{H}_{0}$ : the distribution functions of the analysed distribution are equal - the opinion about the existence of a strategic document in the commune does not diversify the answers to questions from the variables under analysis, $\mathrm{H}_{1}$ : the distribution functions of the analysed distribution are different - the opinion about the existence of a strategic document in the commune diversifies the answers to questions from the variables under analysis. We compare the set value $P$ (in the tables it is referred to as "asymptotic significance" with the significance level of $\alpha$ : if $\mathrm{p} \leq \alpha$, then we reject $\mathrm{H}_{0}$ and simultaneously adopt $\mathrm{H}_{1}$-there is a relation between the opinion on the existence of strategic documents in the commune and the variable under analysis, if $p>\alpha$ then there is no point to reject $\mathrm{H}_{0}$ - the opinion about the existence of strategic documents in the commune does not determine the variable under analysis.

${ }^{4}$ Due to the fact that data refer to a survey of respondents' opinions and not "hard" data, the author adopted the significance level of 0.1 instead of 0.05 .
} 
management which "embraces all spheres that determine the quality of life assessment in the inhabitants" (Jay, 1996, p. 124). The research conducted on selected self-government entities clearly illustrates the role and importance of communication processes, and points to their dominant forms, the essence of bilateral communication and the importance of mixed communication. The hypotheses are presented here, i.e.

- Mixed forms of communication are an important factor contributing to regional development;

- The processes of communication are a crucial tool of cooperation and create the environment for local and regional development, have been fully verified in the research conducted. It means that diversity of forms and methods of communication and the use of interdisciplinary information flow techniques may guarantee proper local and regional development and be a good prognosis for the development of the state.

Nevertheless, it has to be remembered that all the decisions - including those that lead to the development of regions and the state - made by people are a matter of choice. To manage this modern integrated system based on rationalism and pragmatism means to constantly and systematically improve it, and to remember about good and effective interpersonal communication that is perceived as the inherent element of human life.

The aim of this article is to briefly present the most important elements of communication processes that imply regional and state development. The research topic and the theoretical approach presented here may serve as a material for both researchers and local and regional decision-making entities.

The aim of the article is to describe the most important theoretical and empirical determinants of communication processes that clearly imply local and regional development. To emphasize the crucial factors of economic development of regions and states, one has to approach this process in an interdisciplinary manner. Methods and techniques of communication significantly gain in importance. In the long term, the development of a state will be determined by a continuous development of regions, assisted by the processes of communication. This is a real challenge for those who seek new methods of effective management.

\section{References}

Augsburger, D. (1973). The love fight. Scottsdale, PA: Herald Press.

Barrett-Lennard, G. T. (1962). Dimensions of therapist response as causal factors in therapeutic change. Psychological Monographs: General and Applied, 76(43), 1-36.

Blythe, J. (2002). Komunikacja marketingow. Warszawa: Polskie Wydawnictwo Ekonomiczne.

Bolton, R. (1979). People skills: How to assert yourself, listen to others, and resolve conflicts. Englewood Cliffs, NJ: Prentice-Hall.

Brdulak, J. (2001). Problemy rozwoju regionalnego. Warszawa: Dom Wydawniczy Balona.

Buber, M. ( 1959). Hasidism and modern man. M. Fridman, New York: Harper \& Row.

Czekaj, J. (2000). Metody zarzqdzania informacja w przedsiębiorstwie. Kraków: Wydawnictwo Akademii Ekonomicznej w Krakowie.

Forgas, J. ( 1981). Affective and emotional influences on episode representations. In J. Forgas (Ed.), Social cognition: Perspectives on everyday understanding. London: Academic Press.

Gierszewska, G., \& Romanowska, M. (1994). Analiza strategiczna przedsiębiorstwa. Warszawa: Państwowe Wydawnictwo Ekonomiczne.

Gobillot, E. (2008). Przywództwo przez Integracje. Budowanie sprawnych organizacji dla ludzi, osiaganie efektywności i zysku. Kraków: Oficyna Wolters Kluwer.

Goleman, D. (1997). Inteligencja emocjonalna. Poznań: Wydownictwo Media Rodzina.

Griffin, R. (2006). Podstawy zarzadzania organizacjami. Warszawa:Wydawnictwo Naukowe PWN.

Jay, A. (1996). Machiavelli $i$ zarzqdzanie. Autorytet $i$ władza w przedsiębiorstwie. Warszawa: Polskie Wydawnictwo Ekonomiczne. 
Kagan, N. (1975). Interpersonal process recall: A method of influencing human interaction. Ann Arbor: Michigan State University.

Majewski, P. (2007). Czas na e- biznes. Gliwice: Helion.

Potocki, A., Winkler, R., \& Żbikowska, A. (2003). Techniki komunikacji w organizacjach gospodarczych. Warszawa: Wydawnictwo Difin.

Rzepka, A. (2016). Correlation and dependence between: Business - Globalisation-Information society and the global society. International Journal of Business and Management Invention, 5(1), 39-45. 